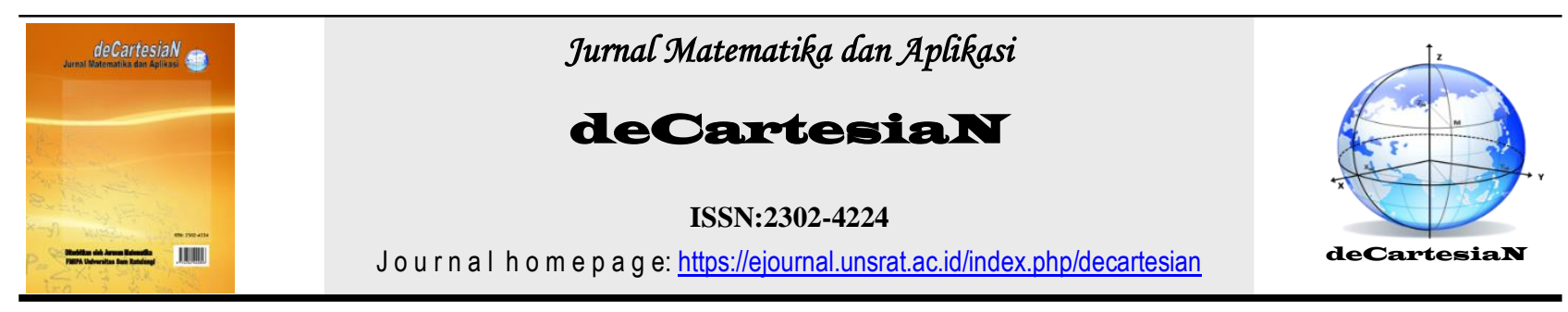

\title{
Pengaruh Pelatihan Dasar Komputer dan Teknologi Informasi bagi Guru-Guru dengan Uji-T Berpasangan (Paired Sample T-Test)
}

\author{
Chriestie E. J. C. Montolalu ${ }^{1 *}$, Yohanes A.R. Langi ${ }^{1}$ \\ ${ }^{1}$ Program Studi Matematika-Fakultas Matematika dan Ilmu Pengetahuan Alam Universitas Sam Ratulangi Manado, Indonesia \\ *Corresponding author : chriestelly@yahoo.com
}

\section{A B S T R A K}

Perkembangan dunia komputer dan teknologi informasi dewasa ini telah mempengaruhi pola kerja dan aktivitas setiap individu. Tidak terkecuali dalam dunia pendidikan. Guru-guru di zaman komputerisasi seperti sekarang ini dituntut untuk bisa melengkapi kemampuan diri dengan keterampilan komputer dan penggunaan teknologi informasi dalam proses pembelajaran dan juga dalam tugas-tugas administrasi. Namun, beberapa kendala termasuk di dalamnya usia yang tidak muda lagi, terkadang menjadi masalah bagi guru-guru untuk memanfaatkan komputer dan teknologi informasi dalam tugas-tugasnya. Di lain pihak, siswa SD zaman sekarang sudah tidak asing lagi dengan dunia komputer dan internet. Namun demikian, penggunaannya seringkali tidak terkontrol dan tidak tepat sasaran akibat kurangnya pemahaman dan kontrol dari lingkungannya, terlebih khusus di sekolah. Untuk menjawab permasalahan ini, tim akan melaksanakan pelatihan dan sosialisasi penggunaan komputer dan teknologi informasi bagi guru-guru dan siswa-siswa di SD GMIM Kinilow dan SD Katolik Kinilow. Kedua sekolah ini dipilih sebagai mitra antara lain karena perkembangan dunia komputer dan teknologi informasi di kedua sekolah ini cukup signifikan. Hal ini antara lain disebabkan lokasi kedua sekolah ini yang memudahkan berbagai akses dengan ibukota provinsi Sulawei Utara.
\end{abstract}

\author{
INFO ARTIKEL \\ Diterima : 20 Maret 2018 \\ Diterima setelah revisi : 27 Maret 2018 \\ Tersedia online $\quad: 15$ April 2018
}

\section{PENDAHULUAN}

Perkembangan teknologi pada beberapa tahun terakhir secara signifikan telah membawa perubahan pada berbagai bidang. Kecanggihan dunia modern yang tidak bisa terlepas dari peran komputer serta perkembangan teknologi informasi dan komunikasi perlahan-lahan menuntut kecakapan serta kesiapan setiap individu yang produktif di zaman ini untuk bisa menguasainya. Terlebih khusus dalam dunia pendidikan, mulai dari penunjang proses belajar mengajar sampai pada urusan administrasi sekolah telah mulai dimodernisasi dengan komputer dan perangkat teknologi informasi lainnya. Bahkan dalam pengembangannya, ujian nasional mulai dipersiapkan untuk dilaksanakan dengan berbasis komputer [1].

Guru-guru dituntut untuk tidak hanya bisa menguasai bidang ilmunya masing-masing, tapi juga harus bisa menguasai cara pengoperasian komputer dan mengakses fasilitas teknologi informasi untuk membantu pengembangan tugas-tugas pembelajarannya [2] sebagaimana juga diatur dalam Permendiknas No.16/2007 tentang Standar Kualifikasi dan Kompetensi Guru [3]. Bahkan Ujian Kompetensi guru dilaksanakan berbasis komputer dan guru diminta melengkapi data pribadinya secara online pada data pokok pendidikan (dapodik).

Keharusan menguasai komputer dan teknologi informasi bagi para guru tidak mudah. Bagi guru-guru berusia muda yang telah mengenal komputer pada saat sekolah dan kuliah mungkin tidak akan mengalami kesulitan, namun bagi guru-guru yang telah berusia lebih tua yang tidak pernah mengenal komputer selama hidupnya, hal ini jelas akan menjadi kendala. Kenyataan tersebut bisa ditemukan oleh peneliti ketika melakukan survei di dua sekolah (SD GMIM Kinilow dan SD Katolik Kinilow). 80\% guru di masing-masing sekolah tersebut mengaku masih mengalami kesulitan dalam mengoperasikan komputer dan bahkan ada yang tidak pernah menggunakan komputer dan hanya mengandalkan bantuan orang lain dalam mengerjakan tugas-tugas administrasinya. Hal ini dikarenakan sebagian besar guru di masing-masing sekolah tersebut telah berusia di atas 45 tahun, yang jelas mereka tidak pernah mengenal komputer pada masa muda mereka. 
SD GMIM Kinilow dan SD Katolik Kinilow beralamat di kelurahan Kinilow I, kecamatan Tomohon Utara, Kota Tomohon. Perkembangan komputer dan teknologi informasi di tempat ini cukup pesat. Salah satu penyebabnya adalah keluarahan Kinilow I terletak strategis sebagai pintu masuk Kota Tomohon yang dihubungkan langsung oleh jalan raya menuju ibukota povinsi Sulawesi Utara, yaitu Kota Manado. Hal ini menjadi salah satu perhatian bahwa pastinya setiap perkembangan dunia komputer dan teknologi informasi di tahun-tahun mendatang akan berpengaruh secara langsung dan cepat pada kehidupan warga Kinilow I.

Berdasarkan hal-hal tersebut, dunia pendidikan khususnya sekolah-sekolah dasar yang ada di kelurahan ini sebaiknya semakin memperlengkapi unsur-unsurnya dengan perkembangan-perkembangan dunia komputer dan teknologi informasi tersebut. Guru-guru adalah pihak utama yang harus menyesuaikan diri dengan perkembangan ini. Dengan menguasai keterampilan dasar komputer dan teknologi informasi, guru-guru akan mendapatkan kemudahan dalam menyiapkan tugas-tugas administrasi dan perangkat pembelajaran mereka, bahkan nantinya bisa menerapkannya dalam proses pembelajaran yang berbasis pada komputer dan teknologi informasi. Selain itu, penguasaan komputer dan teknologi informasi akan membantu tugas para guru dalam mengontrol aktivitas anak-anak didiknya yang semakin dipengaruhi oleh gaya hidup modern dengan komputer dan perangkat teknologi informasi lainnya.

Kenyataan yang didapat ini menjadi tantangan bagi Tim Peneliti untuk memberikan kontribusi melalui Ilmu Pengetahuan yang sudah diperoleh. Berdasarkan latar belakang ilmu yang dimiliki oleh Tim Pelaksana, keadaan-keadaan yang ditemui bisa dijembatani dengan memberikan pelatihan dan pengembangan keterampilan dasar komputer dan teknologi informasi bagi guru-guru dan siswa di kedua sekolah tersebut. Khusus untuk para guru bisa dilatih penggunaan program-program Microsoft (khususnya Microsoft Word, Microsoft Excel, dan PowerPoint) dan penggunaan internet untuk menunjang tugas-tugas mereka. Sementara untuk siswa-siswa bisa diarahkan penggunaan komputer yang tepat seperti menggunakan Microsoft Word untuk membuat tugas sekolah dan memanfaatkan internet untuk mencari referensi tugas sekolah dan pembelajaran mereka.

\section{UJI-T BERPASANGAN}

Populasi dalam kegiatan ini adalah guru-guru kelas 1-6 SD GMIM Kinilow dan SD Katolik Kinilow sebanyak 17 orang. Penelitian yang dilakukan adalah penelitian eksperimen yang bertujuan untuk menyelidiki hubungan sebab akibat perlakuan tertentu terhadap suatu variabel kemudian mengobservasi efeknya [4]. Desain eksperimen yang digunakan adalah Pretest-Postest Control Group Design. Langkahlangkah pelaksanaan kegiatan dalam penelitian ini adalah sebagai berikut:

- $\quad$ pretest tentang Microsoft Word, Microsoft Excel, Microsoft PowerPoint, dan pengetahuan umum tentang teknologi informasi.

- dilanjutkan dengan pelatihan tentang bagaimana mengoperasikan dan menggunakan perangkat lunak Microsoft Word untuk diterapkan para guru dalam menyiapkan bahan ajar dan menyusun administrasi kepegawaian.
- pelatihan tentang bagaimana mengoperasikan dan menggunakan perangkat lunak Microsoft Excel untuk diterapkan para guru dalam mengaplikasikan perhitungan dan pembuatan tabel dan grafik.

- pelatihan tentang bagaimana mengoperasikan dan menggunakan perangkat lunak Microsoft PowerPoint untuk diterapkan para guru dalam menyiapkan bahan presentasi untuk proses belajar mengajar maupun keperluan presentasi lainnya.

- pengenalan dan pelatihan penggunaan internet untuk mencari sumber informasi dan pengetahuan tambahan untuk digunakan para guru dalam mengembangkan bahan ajar dan melengkapi perkembangan pengetahuan.

- $\quad$ posttest tentang materi yang telah diberikan.

Data hasil pretest dan posttest akan diuji dengan uji-t (t-test) dengan bantuan software Statistika.

Uji-t berpasangan (paired t-test) adalah salah satu metode pengujian hipotesis dimana data yang digunakan tidak bebas (berpasangan). Ciri-ciri yang paling sering ditemui pada kasus yang berpasangan adalah satu individu (objek penelitian) mendapat 2 buah perlakuan yang berbeda. Walaupun menggunakan individu yang sama, peneliti tetap memperoleh 2 macam data sampel, yaitu data dari perlakuan pertama dan data dari perlakuan kedua.

Hipotesis dari kasus ini dapat ditulis:

$$
\begin{aligned}
& H_{0}=\mu_{1}-\mu_{2}=0 \\
& H_{1}=\mu_{1}-\mu_{2} \neq 0
\end{aligned}
$$

$H_{a}$ berarti bahwa selisih sebenarnya dari kedua rata-rata tidak sama dengan nol.

\section{Rumus uji-t berpasangan}

dimana:

$$
t_{\text {hit }}=\frac{\bar{D}}{\frac{S D}{\sqrt{n}}}
$$

$$
\begin{gathered}
S D=\sqrt{\operatorname{var}} \\
\operatorname{var}\left(s^{2}\right)=\frac{1}{n-1} \sum_{i=1}^{n}\left(x_{i}-\bar{x}\right)^{2}
\end{gathered}
$$

$\mathrm{t}=$ nilai $\mathrm{t}$ hitung

$\bar{D}=$ rata-rata selisih pengukuran 1 dan 2

$S D=$ standar deviasi selisih pengukuran 1 dan 2 $n=$ jumlah sampel.

\section{Interpretasi}

a) untuk menginterpretasikan uji t-test terlebih dahulu harus ditentukan:

- Nilai signifikansi $\alpha$

- $\quad D f$ (degree of freedom) $=N-k$, khusus untuk paired sample t-test $\mathrm{df}=N-1$

b) bandingkan nilai $t_{\text {hit }}$ dengan $t_{t a b=\alpha ; n-1}$

c) apabila:

$t_{\text {hit }}>t_{\text {tab }} \rightarrow$ berbeda secara signifikan $\left(H_{0}\right.$ ditolak $)$

$t_{\text {hit }}<t_{\text {tab }} \rightarrow$ tidak berbeda secara signifikan $\left(H_{0}\right.$ diterima)

\section{HASIL DAN PEMBAHASAN}

Data perlakuan pertama dalam penelitian ini ditentukan melalui nilai hasil pretest dan data perlakuan kedua ditentukan melalui nilai hasil posttest. Data kedua perlakuan dapat dilihat pada tabel 1. 
Tabel 1. Data nilai sebelum perlakuan (pretest) dan sesudah perlakuan (posttest).

\begin{tabular}{|c|c|}
\hline $\begin{array}{c}\text { Data Sebelum } \\
\text { (pretest) }\end{array}$ & $\begin{array}{c}\text { Data Sesudah } \\
\text { (posttest) }\end{array}$ \\
\hline 50.00 & 70.00 \\
\hline 55.00 & 73.00 \\
\hline 55.00 & 82.00 \\
\hline 45.00 & 79.00 \\
\hline 48.00 & 77.00 \\
\hline 60.00 & 80.00 \\
\hline 53.00 & 75.00 \\
\hline 47.00 & 72.00 \\
\hline 52.00 & 68.00 \\
\hline 62.00 & 92.00 \\
\hline 57.00 & 76.00 \\
\hline 43.00 & 72.00 \\
\hline 49.00 & 68.00 \\
\hline 54.00 & 71.00 \\
\hline 56.00 & 70.00 \\
\hline 61.00 & 90.00 \\
\hline 41.00 & 69.00 \\
\hline
\end{tabular}

Data pada tabel 1 dianalisis dengan uji-t menggunakan software statistika. Hasil analisis dapat dilihat pada tabel 2, 3, dan 4 .

Tabel 2. Paired Samples Statistics

\begin{tabular}{|c|r|r|r|r|}
\hline & Mean & $\mathrm{N}$ & $\begin{array}{c}\text { Std. } \\
\text { Deviati } \\
\text { on }\end{array}$ & $\begin{array}{c}\text { Std. } \\
\text { Error } \\
\text { Mean }\end{array}$ \\
\hline Pair 1 sebelu & 52.235 & 17 & 6.1900 & 1.5013 \\
$\mathrm{~m}$ & 3 & & 0 \\
sesuda & 75.529 & 17 & 7.1860 & 1.7428 \\
$\mathrm{~h}$ & 4 & & 8 & 8 \\
\hline
\end{tabular}

Tabel 3. Paired Samples Correlations

\begin{tabular}{|ll|r|r|r|}
\hline & & $\begin{array}{c}\text { Correlatio } \\
\mathrm{n}\end{array}$ & Sig. \\
\hline $\begin{array}{l}\text { Pair } \\
1\end{array}$ & $\begin{array}{l}\text { sebelum } \\
\text { sesudah }\end{array}$ & 17 & .615 & .009 \\
\hline
\end{tabular}

Tabel 4. Paired Samples Test

\begin{tabular}{|c|c|c|c|c|c|c|c|c|}
\hline & \multicolumn{5}{|c|}{ Paired Differences } & \multirow[b]{3}{*}{$\mathrm{t}$} & \multirow{3}{*}{\multicolumn{2}{|c|}{$\begin{array}{c}\text { Sig. } \\
(2- \\
\text { df }\end{array}$}} \\
\hline & \multirow[b]{2}{*}{ Mean } & \multirow{2}{*}{$\begin{array}{c}\text { Std. } \\
\text { Deviati } \\
\text { on }\end{array}$} & \multirow{2}{*}{$\begin{array}{l}\text { Std. } \\
\text { Error } \\
\text { Mean }\end{array}$} & \multicolumn{2}{|c|}{$\begin{array}{l}95 \% \text { Confidence } \\
\text { Interval of the } \\
\text { Difference }\end{array}$} & & & \\
\hline & & & & Lower & Upper & & & \\
\hline $\begin{array}{ll}\text { Pai } & \\
& \text { sebelu } \\
& \text { n dan } \\
& \text { sesuda } \\
& n\end{array}$ & $\begin{array}{c}- \\
23.29412\end{array}$ & $\begin{array}{c}5.9346 \\
9\end{array}$ & $\begin{array}{c}1.4393 \\
7\end{array}$ & 26.34546 & 20.24278 & 16.183 & 316 & .000 \\
\hline
\end{tabular}

Tabel 4 menunjukkan hasil uji-t sebesar 16,183. Dengan nilai signifikan $\alpha$ sebesar 0,05, maka $t_{t a b}=2,120$. Sehingga didapatkan kesimpulan bahwa $t_{\text {hit }}>t_{t a b}$. Dengan kata lain, perlakuan yang dilakukan dalam penelitian memberikan pengaruh yang cukup signifikan terhadap hasil yang diharapkan. Jika dilihat melalui tabel 1, pengaruh yang diberikan oleh hasil penelitian ini adalah pengaruh yang positif bagi peserta dengan adanya peningkatan pemahaman dan pengetahuan.

\section{KESIMPULAN}

Dengan demikian dapat disimpulkan bahwa kegiatan pelatihan keterampilan dasar komputer (Microsoft Word, Microsoft Excell, dan Adobe Photoshop) dan teknologi informasi yang dilakukan dalam penelitian dapat memberikan hasil yang positif bagi peserta.

\section{REFERENSI}

[1] Peraturan Badan Standar Nasional No. 0043/P/BSNP/I/2017.

[2] Mulyana, A.Z. 2010. Rahasia Menjadi Guru Hebat. Grasindo, Jakarta.

[3] Permendiknas No.16/2007.

[4] Jogiyanto. 2008. Metodologi Penelitian Sistem Informasi. Andi Offset, Yogyakarta.

Chriestie E.J.C Montolalu (chriestelly@yahoo.com)

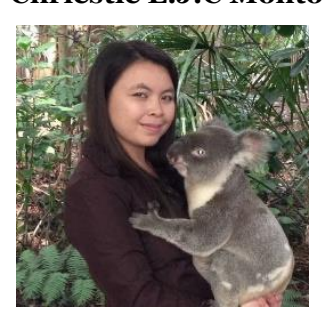

Pada tahun 2007, gelar Sarjana Sains (S.Si) diperoleh dari Universitas Sam Ratulangi Manado.

Gelar Master of Science (M.Sc) diperoleh dari Universitas of Queensland Australia pada tahun 2015.

Bekerja di Program Studi Matematika UNSRAT sebagai pengajar akademik (Dosen) mulai dari tahun 2008 sampai sekarang.

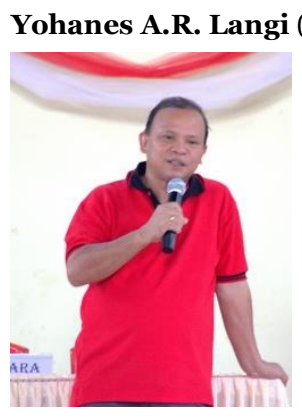
arlangi@unsrat.ac.id)

Pada tahun 1994, memperoleh gelar sarjana di Departemen Matematika, Fakultas Matematika dan Ilmu Pengetahuan Alam, Universitas Kristen Tomohon.

Gelar magister bidang Biometrika Hutan diperoleh dari Departemen Biometrika, Institut Pertanian Bogor, pada tahun 2007.

Menjadi dosen di Departemen Matematika, FMIPA, Universitas Sam Ratulangi Manado sejak tahun 2005 sampai sekarang. 